\title{
Trypanosomatids of four Loricariidae fish species in western Amazon rivers
}

\section{Tripanossomatídeos de quatro espécies de peixes Loricariidae em rios da Amazônia ocidental}

\author{
L. R. Virgílio ${ }^{12}$; G. O. Teixeira²; L.S. Almeida²; H. P. S. Melo²; S. L. Prolo Júnior²; D. U.O. \\ Meneguetti ${ }^{1}$; L. M. A. Camargo ${ }^{3}$, R. M. Takemoto ${ }^{5}$ \\ ${ }^{1}$ Universidade Federal do Acre (UFAC), Rio Branco \\ 2 Universidade Federal do Acre, Campus Floresta \\ ${ }^{3}$ Universidade Federal do Acre, Colégio de Aplicação \\ ${ }^{4}$ Universidade de São Paulo \\ ${ }^{5}$ Universidade Estadual de Maringá \\ *lurunita@gmail.com
}

\section{RESUMO}

The presence of trypanosomatids in fish is well known and can occur in many fish species worldwide. In this sense, this study aims to report the occurrence of Trypanosoma sp. in four species of the Loricariidae family in the western Amazon, as well as the morphology of these hemoparasites. The fish were collected in three sub-basins of the states of Acre and Amazonas, Brazil. Fish blood samples were collected by cardiac puncture, with smears made for quantification, morphometric measurements, and morphotyping of the trypanosomes found. We estimated the prevalence and parasitism density data. The morphometric variables of Trypanosoma sp. were subjected to analysis of variance. We found new reports of Trypanosoma distribution and occurrence in Loricariidae species for western Amazonia. The examined fish showed infection by more than one Trypanosoma spp. morphotype A has been identified infecting Loricariichthys anus, Sturisoma cf. robustum, and Loricaria cataphracta, morphotype B occurred in all fish species, and morphotypes C, D, and E occurred only in Loricaria sp. There was a significant difference between the morphotypes according to the morphometric parameters. Thus, this study significantly clarified the morphological variation, distribution, and diversity of Trypanosoma hosts.

Palavras-chave: Neotropical; Hemoparasitism; Morphotype; Distribution.

\section{ABSTRACT}

A presença de tripanossomatídeos em peixes é bem conhecida e pode ocorrer em muitas espécies de peixes em todo o mundo. Nesse sentido, este estudo tem como objetivo relatar a ocorrência de Trypanosoma em quatro espécies da família Loricariidae na Amazônia ocidental, bem como a morfologia desses hemoparasitas. Os peixes foram coletados em três sub-bacias dos estados do Acre e Amazonas, Brasil. Amostras de sangue de peixes foram coletadas por punção cardíaca, com esfregaços feitos para quantificação, medidas morfométricas e morfotipagem dos tripanossomas encontrados. Estimamos os dados de prevalência e densidade de parasitismo. As variáveis morfométricas de Trypanosoma sp. foram submetidos à análise de variância. Encontramos novos relatos de distribuição e ocorrência de Trypanosoma em espécies de Loricariidae para a Amazônia ocidental. Os peixes examinados mostraram infecção por mais de um Trypanosoma o morfotipo A foi identificado infectando Loricariichthys anus, Sturisoma robustum e Loricaria cataphracta, o morfotipo B ocorreu em todas as espécies de peixes, e os morfotipos C, D e E ocorreram apenas em Loricaria sp. Houve diferença significativa entre os morfotipos de acordo 
com os parâmetros morfométricos. Assim, este estudo esclareceu significativamente a variação morfológica, distribuição e diversidade dos hospedeiros de Trypanosoma.

Keywords: Neotropical; Hemoparasitismo; Morfotipo; Distribuição.

\section{INTRODUCTION}

The fish fauna of the Loricariidae family (Actinopterygii: Siluriformes) is one of the most diverse within the order Siluriformes (NELSON, 1994), playing an important role in aquatic ecosystems (BUCKUP, 1999). Besides, they have a high export potential in the aquarium market, which increases the scientific and economic level of these organisms (SANTOS et al., 2005).

Loricariids are commonly defined as detritivorous species with a tendency to algivory. They are scrapers with benthic and semi-sedentary habits (DELARIVA e AGOSTINHO, 2001), which can, according to Froés et al. (1979), make them potential fish hosts for leeches (Hirudinea). These invertebrates may develop Trypanosoma infection and transmit these hemoparasites to their host fish (JONES e WOO 1991).

Trypanosomatidae (Kinetoplastida) have a single nucleus, are elongated with a flagellum or rounded with a very short flagellum, and do not live freely. Many members of this family are heteroxenous, living a phase of life in the bloodstream or many tissues of different aquatic vertebrates (fish, amphibians, and reptiles), and another phase in the intestine of invertebrates, such as Hirudinea (CORRÊA et al., 2016).

These hemoparasites may not be harmful to infected fish, however in some cases, depending on the degree of infection, they can cause vital changes in the blood and some organs, causing anemia and anorexia (AHMED et al., 2011; LEMOS et al., 2015; MAQBOOL e AHMED 2016).

The presence of these trypanosomatids in fish is well known in the literature, occurring in more than 200 species of teleosts and elasmobranchs in marine and freshwater environments worldwide (EIRAS et al. 2012; GUPTA e GUPTA, 2012). More than 35 species of Trypanosoma have been described only in fish of the Loricariidae family (EIRAS et al. 2012). In the Amazon, few studies have been carried out on the distribution and occurrence of Trypanosoma in fish (FUJIMOTO et al., 2013; CORRÊA et al., 2016; NEVES et al., 2018; De SOUZA e CORRÊA, 2019), which may indicate a 
knowledge gap about these hemoparasites. This gap is mainly due to the region's high fish species diversity (REIS et al., 2016). Thus, identifying new Trypanosoma hosts is crucial since this information can help to solve significant problems regarding the study of pathogens caused by these parasites, in addition to contributing to the phylogeny of the trypanosomatid group (LOM, 1979).

In this sense, the present study aims to report the occurrence of Trypanosoma sp. in four species of the Loricariidae family in western Amazonia and to evaluate the morphology of these hemoparasites in individuals of the same and different species of fish.

\section{MATERIALS AND METHODS}

\section{Study area}

The fish were collected (authorization from the Brazilian Institute of the Environment and Renewable Natural Resources No. 59642-2/2019) in the northwestern regions of the state of Acre and extreme southwest of the state of Amazonas, around the municipalities of Cruzeiro do Sul - AC and Guajará - AM, Brazil (Figure 1). Three subbasins were selected in these regions: (i) Juruá River (740'34.1"S 72³9'39.5"W); (ii)

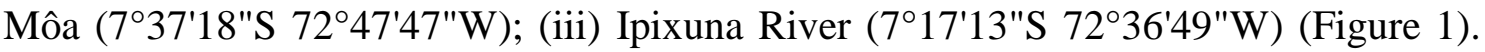
Studies of Trypanosoma in Loriicaridae fish in the Amazon were carried out only in the eastern region (Figure 1, Table 1).

Figure 1. Distribution of Trypanosoma spp. found in fish species of the Loricariidae family in the Legal Amazon. 

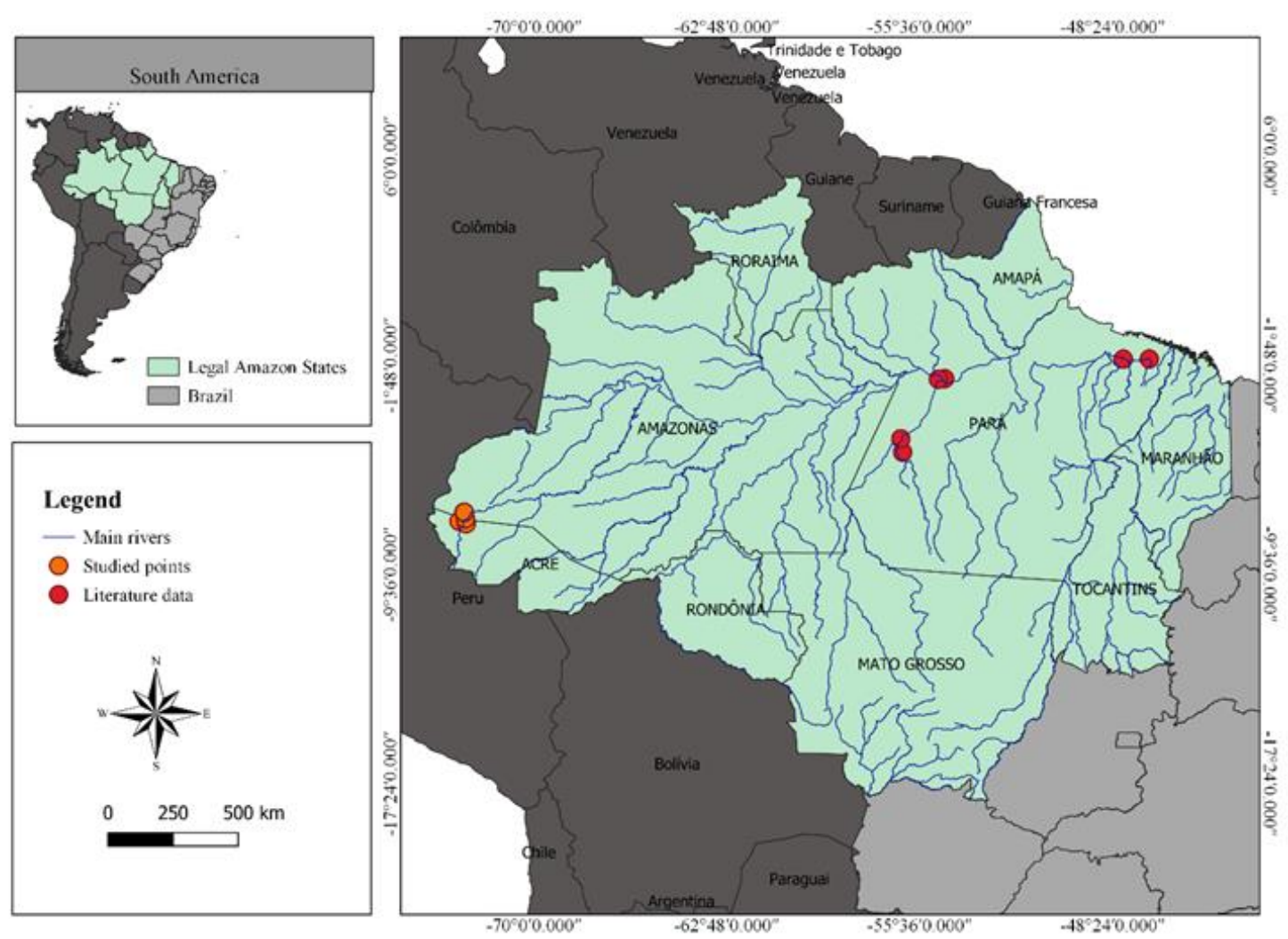

Table 1. Fish species of the family Loricariidae that had infection by Trypanosoma in the Legal Amazon.

\begin{tabular}{lcc}
\hline \multicolumn{1}{c}{ Species } & Local & Reference \\
\hline Pterygoplichthys pardalis & Pacoval Lake, PA & \\
Hypostomus sp. & Tapajós River, PA & SOUZA e CORRÊA, \\
Squaliforma sp. & Tapajós River, PA & 2019 \\
Lamontichthys cf. stibaros & Tapajós River, PA & \\
Hypostomus sp. & Uruá Stream/Jamaxinzinho River & \\
Leporacanthicus galaxias & Guamá River, PA & CORRÊA et al., 2016 \\
Lasiancistrus saetiger & Guamá River, PA & \\
Cochliodon sp. & Guamá River, PA & \\
Pseudacanthicus spinosus & Guamá River, PA & \\
Rineloricaia cf. lanceolata & Guamá River, PA & \\
Hypostomus sp. & Guamá River, PA & FUJIMOTO et al., 2013 \\
Ancistrus sp. & Guamá River, PA & \\
Peckoltia oligospila & middle Guamá River, PA & \\
Cochliodon sp. & middle Guamá River, PA & \\
Lasiancistrus saetiger & middle Guamá River, PA & NEVES et al., 2018 \\
Pseudocanthicus spinosus & middle Guamá River, PA & \\
\hline
\end{tabular}

\section{Sampling}

Fish sampling was carried out (authorization from the Brazilian Institute of Environment and Renewable Natural Resources No. 59642-2 / 2019) using gillnets of 80 
$\mathrm{m}$ long and $3.0 \mathrm{~m}$ high, with meshes sizes of $1.5 \mathrm{~cm}, 2.5 \mathrm{~cm}, 3.5 \mathrm{~cm}$, and $5.5 \mathrm{~cm}$ between opposing nodes. We used two nets, each with $12 \mathrm{~mm}$ mesh, $2 \mathrm{~m}$ high, and $12 \mathrm{~m}$ open. The nets were launched ten times at each collection point. We also used beach trawls of $9 \mathrm{~m}$ long and $2.4 \mathrm{~m}$ high, with a $13 \mathrm{~mm}$ mesh. The fish collected were sent to the Aquatic Ecology Laboratory of the Federal University of Acre (UFAC), where they were identified, measured, and weighed.

We examined five specimens of Loricaria sp., Loricariichthys anus, Sturisoma cf. robustum, and Loricaria cataphracta.

The specimens collected were anesthetized using menthol in a similar way to benzocaine. Menthol has many characteristics that qualify it as a suitable anesthetic for fish due to its efficacy and a sufficient safety margin for fish and the operator in the concentration used (GOMES et al., 2001). Then, to assess the presence of hemoparasites, blood samples were collected by cardiac puncture, using a hypodermic syringe containing an anticoagulant (5\% EDTA), with duplicate blood smears made per fish sample. The blood smears were stained using Quick Panoptic/LABORCLIN® and examined by optical microscopy with 400x and 1000x magnification in the Microscopy Laboratory I at the Federal University of Acre (UFAC), Cruzeiro do Sul Campus, Acre, Brazil.

We selected ten Trypanosoma specimens of each morphotype for the morphometric evaluation. The parasites found were photographed using a Leica DM 500 optical microscope with an ICC50 HD coupled camera. The photos were used to determine the morphometric characteristics of the trypanosomatids using the ImageJ software, and the cytomorphometric measurements of the trypanosomatids were performed according to Borges (2016) (Figure 2). 
Fig. 2. Scheme of the morphometric measurements of trypanosomatids found in P. armatulus, based on Borges et al. (2016). Total body length (TL); Body length (BL); Nucleus length (NL); Kinetoplast length (KL); Free flagellum length (F); Body width (BW); Nucleus width (NW); Kinetoplast width (KW); Distance from the posterior end to the kinetoplast center (PK); Distance from the kinetoplast center to the nucleus center (NK); Distance from the anterior end to the nucleus center (NA); Distance from the posterior end to the nucleus center (NP).

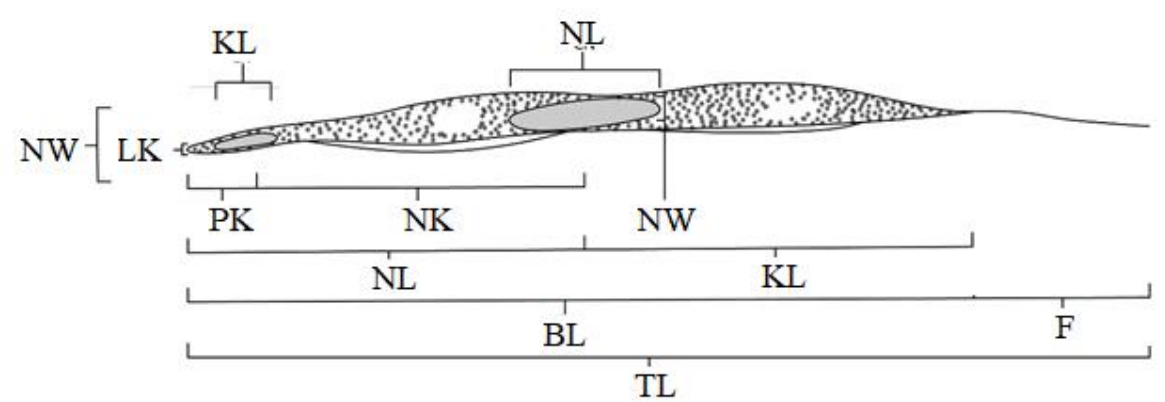

\section{Data analysis}

The parameters of prevalence were calculated according to Bush et al. (1997). We used the direct method, adapted from De Carli (2001), to estimate the infection intensity (expressed in parasites/mL). We recorded and calculated all parasites found in 100 microscopic fields using 1000x magnification. It is estimated that 100 microscopic fields are equivalent to $0.2 \mu \mathrm{L}$ of blood. Thus, the intensity of infection $=$ (number of parasites $\times 5) \times 1,000=($ parasites $/ \mathrm{mL})($ De SOUZA e CORRÊA, 2019).

The morphometric variables of Trypanosoma spp. underwent homoscedasticity (Levene) and normality (Shapiro-Wilk) tests. Thus, we used an analysis of variance (ANOVA) followed by Tukey's post-hoc test to verify whether there was a difference in morphometric parameters among the morphotypes of Trypanosoma sp. Analyses were performed using the R software version 3.6.1.

\section{RESULTS}

Most studies on trypanosomes of Loricariidae in the Amazon have hitherto been concentrated in the eastern Amazon, where Hypostomus was the most studied genus (Table 1).

The present study shows new reports of Trypanosoma distribution and occurrence in four Loricariidae fish species for the western Amazon.

The fish species examined showed infection by more than one morphotype of Trypanosoma. Morphotype A has been identified infecting Loricariichthys anus, 
Sturisoma cf. robustum, and Loricaria cataphracta, morphotype B occurred in all fish species, and morphotypes C, D, and E occurred only in Loricaria sp. (Tables 2 and 3).

Table 2. Parasite indices in fish of the Loriicaridae family with Trypanosoma infection in the western Amazon.

\begin{tabular}{lcccc}
\hline Parameters & Loricaria sp. & L. anus & Sturisoma cf. robustum & L. cataphracta \\
\hline Examined & 5 & 5 & 5 & 5 \\
Parasitized & 5 & 2 & 5 & 3 \\
Prevalence & $100 \%$ & $40 \%$ & $100 \%$ & $60 \%$ \\
Range of Intensity & $1-18$ & $1-5$ & $1-9$ & $2-6$ \\
Parasitemia & $6.10^{4}$ & $1.10^{4}$ & $45.10^{3}$ & $3.10^{4}$ \\
Total number of parasites & 146 & 13 & 10 & 8 \\
\hline
\end{tabular}

Table 3. Morphometric parameters of Trypanosoma morphotypes found in four fish species of the Loricariidae family. Total body length (TL); Body length (BL); Nucleus length (NL); Kinetoplast length (KL); Free flagellum length (F); Body width (BW); Nucleus width (NW); Kinetoplast width (WK); Distance from the posterior end to the kinetoplast center (PK); Distance from the kinetoplast center to the nucleus center (NK); Distance from the anterior end to the nucleus center (NA); Distance from the posterior end to the nucleus center (PN).

\begin{tabular}{lccccccc}
\hline Measurements & Morph. A & Morph. B & Morph. C & Morph. D & Morph. E & F & p \\
\hline TL & $68.10 \pm 5.3$ & $54.12 \pm 3.72$ & $56.32 \pm 3.12$ & $54.03 \pm 4.0$ & $70.0 \pm 1.36$ & 24.10 & 0.001 \\
BL & $48.39 \pm 6.2$ & $35.67 \pm 3.55$ & $36.20 \pm 5.64$ & $35.25 \pm 10.42$ & $62.40 \pm 4.31$ & 18.69 & 0.001 \\
NL & $2.84 \pm 0.5$ & $2.93 \pm 0.67$ & $3.52 \pm 0.16$ & $3.71 \pm 0.09$ & $3.87 \pm 0.35$ & 73.112 & 0.01 \\
KL & $1.01 \pm 0.25$ & $0.90 \pm 0.23$ & $0.88 \pm 0.19$ & $1.02 \pm 0.16$ & $1.13 \pm 0.15$ & 0.88 & 0.47 \\
F & $20.03 \pm 2.68$ & $18.55 \pm 2.19$ & $17.76 \pm 2.87$ & $18.63 \pm 4.00$ & $12.26 \pm 2.18$ & 5.95 & 0.001 \\
BW & $2.79 \pm 0.73$ & $2.03 \pm 0.42$ & $2.17 \pm 0.24$ & $2.07 \pm 0.91$ & $2.67 \pm 0.20$ & 3.81 & 0.009 \\
NW & $1.86 \pm 0.50$ & $1.39 \pm 0.35$ & $1.34 \pm 0.22$ & $1.40 \pm 0.80$ & $1.72 \pm 0.09$ & 3.46 & 0.51 \\
WK & $0.88 \pm 0.16$ & $0.70 \pm 0.16$ & $0.86 \pm 0.16$ & $0.76 \pm 0.14$ & $0.88 \pm 0.07$ & 2.00 & 0.13 \\
PK & $1.90 \pm 1.3$ & $0.95 \pm 0.38$ & $0.95 \pm 0.09$ & $1.15 \pm 0.12$ & $3.02 \pm 0.58$ & 8.83 & 0.32 \\
NK & $26.99 \pm 9.05$ & $20.89 \pm 5.80$ & $23.98 \pm 3.32$ & $19.49 \pm 7.0$ & $40.17 \pm 7.09$ & 3.69 & 0.01 \\
NA & $19.55 \pm 5.10$ & $16.93 \pm 4.43$ & $10.59 \pm 4.85$ & $11.97 \pm 3.69$ & $20.08 \pm 2.81$ & 4.75 & 0.002 \\
PN & $28.82 \pm 9.33$ & $21.88 \pm 6.03$ & $24.98 \pm 3.39$ & $18.07 \pm 1.3$ & $42.32 \pm 7.02$ & 4.28 & 0.005 \\
\hline
\end{tabular}

Of the four species examined, Sturisoma cf. robustum and Loricaria sp. were the most parasitized species and with the highest prevalence of parasites $(\mathrm{P}=100 \%$ and $\mathrm{P}=$ $100 \%$, respectively). However, Loricaria sp. had a higher number of parasites $(n=146)$ and intensity of parasite infection with $6 \times 10^{4}$ parasites $/ \mathrm{mL}$, whereas Sturisoma cf. robustum was the species with the lowest parasitemia value, $45.10^{3}$ (Table 2).

We selected ten individuals from each Trypanosoma morphotype for morphometric characterization (Table 3). We found a significant difference among the morphotypes 
(TL, BL, NL, F, BW, NK, NA, and PN), according to the morphometric parameters (Table 3). Therefore, morphotypes A and E, LT, BL, and NA were significantly different from the other morphotypes $(\mathrm{p}<0.005)$. Morphotype $\mathrm{E}$ also showed a significant difference between NK and PN and the other morphotypes $(\mathrm{p}<0.005)$. Morphotype B was different, mainly in the BW data, whereas morphotype D was different in PN and morphotype C, NA ( $\mathrm{p}<0.005)$ (Figure 2).

Figure 3. Morphometric parameters showing the differences among trypanosome morphotypes of four Loricariidae species in the western Amazon. A = morphotype A; B $=$ morphotype $\mathrm{B} ; \mathrm{C}=$ morphotype $\mathrm{C} ; \mathrm{D}=$ morphotype $\mathrm{D} ; \mathrm{E}=$ Morphotype $\mathrm{E}$. $\mathrm{TL}=$ total body length; $\mathrm{BL}=$ body length excluding the free flagellum; $\mathrm{NL}=$ nucleus length; $\mathrm{F}=$ length of the free flagellum; BW = body width measured at the nucleus center; $\mathrm{PN}=$ distance from the posterior end to the nucleus center; $\mathrm{NK}=$ distance from the kinetoplast center to the nucleus center; $\mathrm{NA}=$ distance from the anterior end to the nucleus center.
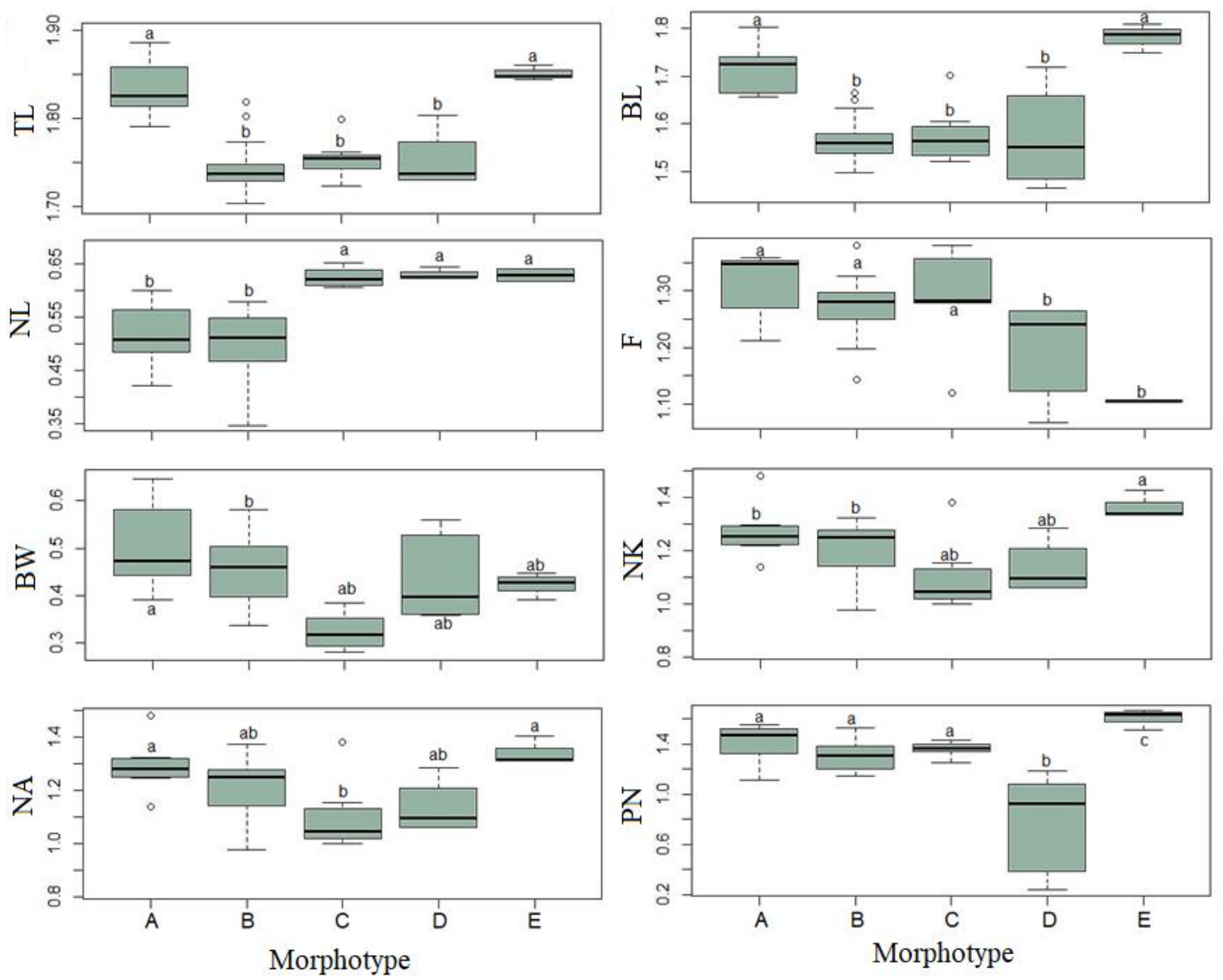

Morphotype A showed both ends of the body tapered, mainly the anterior towards the flagellum, with cytoplasm having vacuole. The free flagellum was relatively short, and the plasmatic membrane was well defined and wavy, extending to the tapered part 
anterior to the flagellum. The nucleus had an oval shape and was located in a posterior position, close to the cell center $(\mathrm{LN}=1.44 \pm 0.11)$, with the sickle-shaped chromatin in all individuals. The kinetoplast had a circular shape and was located close to the posterior end in most individuals observed $(\mathrm{NK}=1.02 \pm 0.01$ ) (Figure 4A). Morphotype $\mathrm{B}$, on the other hand, showed undulations in the anterior part of the body and near the nucleus. This morphotype had 11 cytoplasmic vacuoles, with six in the anterior and five in the posterior part of the nucleus, in which one was close to the kinetoplast. The nucleus had an ovoid and elongated shape, located in a posterior position close to the cell center (IN $=1.28 \pm$ 0.12). The kinetoplast had an oval shape and was located close to the posterior extremity in most individuals observed $(\mathrm{IK}=1.05 \pm 0.04)$. The plasmatic membrane of Trypanosoma sp. was quite wavy and defined, with a medium and flexed flagellum (Figure 4B). Morphotype $\mathrm{C}$ showed no undulation in the plasmatic membrane, and its cytoplasm showed four vacuoles. The portion of the free flagellum was generally long with a curvature, and the nucleus had an oval shape while located in the center of the body $(\mathrm{IN}=1.0 \pm 0.09)$. The kinetoplast had an oval shape while located close to the posterior region ( $\mathrm{IK}=2.0 \pm 0.02$ ) (Figure $4 \mathrm{C}$ ). Morphotype $\mathrm{D}$ had the body with two tapered ends and a plasmatic membrane with two slight undulations, one in the anterior part and the other in the posterior region but anterior to the flagellum. The cytoplasm was composed of two vacuoles, one in the anterior portion and the other posterior to the nucleus, with a slightly undulated and relatively short flagellum. The nucleus had an oval shape and was located slightly towards the anterior part of most parasite bodies $(I N=1.5 \pm 0.11)$. The kinetoplast also had an oval shape located in the posterior region ( $\mathrm{IK}=1.0 \pm 0.01$ ) (Figure 4D). Finally, morphotype E had the cytoplasm with four vacuoles, two closes to the nucleus and two close to both ends, with undulated membrane along the body. The free flagellum was relatively large and undulated. The nucleus had an oval shape while located in the region posterior to the cell center ( $\mathrm{IN}=0.56 \pm 0.11)$ of most parasites. The kinetoplast also had an oval shape, located closer to the posterior end of the nucleus (IK $=1.7 \pm 0.01)($ Figure 4E). 
Figure 4. Forms of trypomastigotes of the Loricariidae species, visualized in $100 \mu \mathrm{m}$ scale. A Morphotype A; B- Morphotype B; C - Morphotype C; D - Morphotype D; E - Morphotype E.

A

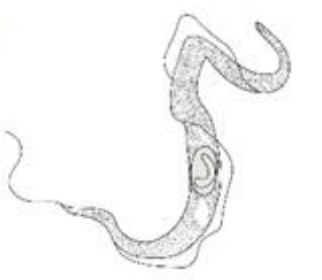

B

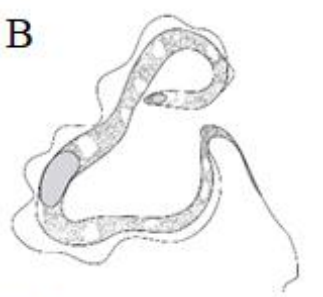

$\mathrm{C}$

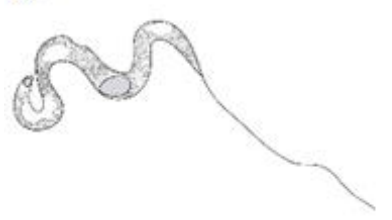

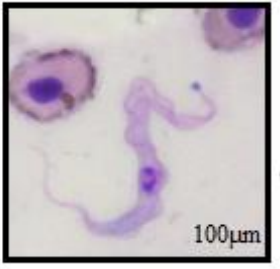

D
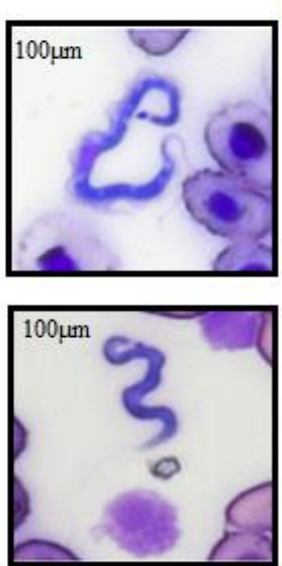
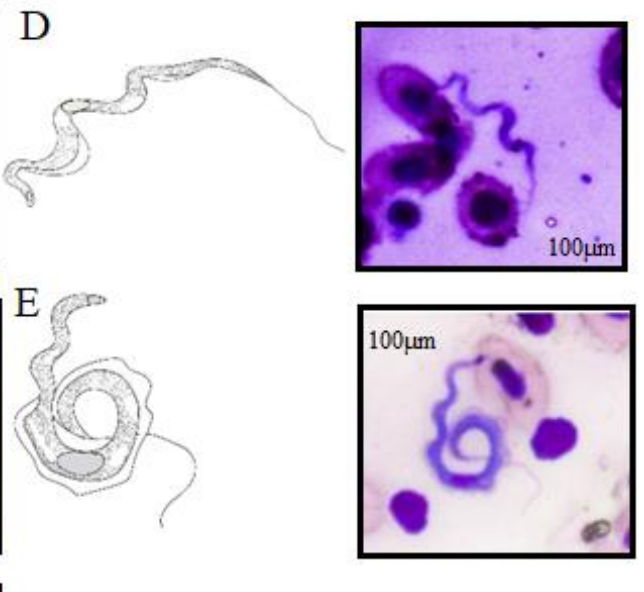

\section{DISCUSSION}

The present study demonstrated that research on Trypanosoma in Loricariidae is concentrated in the eastern Amazon. Here, we reported for the first time the occurrence of Trypanosoma ssp. to the western Amazon, expanding the distribution of these hemoparasites. We also reported trypanosome infection in Loricaria sp., Loricariichthys anus, Sturisoma robustum, and Loricaria cataphracta. Some studies reported trypanosomatids in Loricaria and Loricariichthys species (EIRAS et al., 1998; FROES et al., 1978); however, it is the first report for these hemoparasites in Loricaria cataphracta and Sturisoma cf. robustum. Many fish species may have infections by hemoparasites of the genus Trypanosoma. Loricariidae has the highest number of species with reports of infection (EIRAS et al., 2010, 2012; MOLINA et al., 2016), where the genus Hypostomus is considered the most common host (RIBEIRO et al. 1990).

Loricaria sp. showed a higher prevalence and parasitemia of Trypanosoma sp., in addition to indicating a higher variety of morphotypes. Trypanosoma infection in Loricaria is well documented (FONSECA e VAZ 1929; FONSECA e VAZ, 1928; LOPES et al., 1991; EIRAS et al., 2012) and may be associated with the species' habits, which are usually semi-sedentary. They are found on the margins or backwater regions, 
which may allow a higher infection by ectoparasites, such as leeches, which transmit protozoa (FROÉS et al., 1978). Trypanosoma infections can cause anorexia in infected fish, pronounced in cases of high parasitemia, although fish that survive the disease return to their regular diet (CORRÊA et al., 2016). Anemia can change the body conditions of hosts and somatic indexes of their livers, spleens, and hearts (ARDELLI e WOO, 1998).

The present study indicated many morphological forms of Trypanosoma in the blood of individuals of the same species and among species of Loricariidae. However, we cannot infer that these are different hemoparasite species since trypanosomes can show pleomorphism, which hinders the identification of these individuals (FRÓES et al., 1978). Thus, due to the plasticity of these hemoparasites, molecular tools are crucial for accurate identification (FUJIMOTO et al., 2013). However, the morphological identification of Trypanosoma in fish is essential, since these data can characterize how the infection settles in the blood system. For example, according to some authors (LOM, 1979; LETCH, 1980), during the onset of infection, trypanosomes can show short and thin forms, and as the infection matures, the trypanosomes become long and wide. That is similar to some morphotypes in the same specimen of Loricaria sp. found in the present study. However, morphological studies associated with morphometry are helpful tools to elucidate the diversity of these flagellates, offering a low-cost methodology that can demonstrate the differences between the numerous specimens observed in the hosts' bloodstream (SOUZA e CORRÊA, 2019).

The aspects that expressed, in the present study, the high morphological variation of the blood trypomastigotes of Loricariidae were the changes in the body total length and width (thin or wide forms), the number of undulations in the wavy membrane, the presence and number of cytoplasmic granules, the distance of the kinetoplast to the posterior part, and the free flagellum length. Characteristics that may indicate variation in the development stage of these hemoparasites (LOM, 1979) and confirm the hypothesis that the morphological parameters of the bloodstream trypomastigote forms of fish are weak factors for the differentiation of parasite species (FIGUEROA et al., 1999; KARLSBAKK e NYLUND, 2006; GU et al., 2007).

In this regard, studying Trypanosoma spp. in fish helps to clarify the morphological variation, distribution, and diversity of hosts, aiming to provide information about possible infections of neotropical fish farming and increase the knowledge about the diversity of these hemoparasites. 


\section{REFERÊNCIAS}

AHMED, M.S.; SHAFIQ, K., ALI, H.; OLLEVIER, F. Pathogenic effects associated with Trypanosoma danilewskyi strain FCc 1 infection in juvenile common carp, Cyprinus carpio L. Journal of Animal and Plant Sciences v. 21, n. 4, p. 800-806, 2011.

ARDELLI, B.F.; WOO, P.T.K. Improved Culture Media for Piscine Hemoflagellates, Cryptobia and Trypanosoma (Kinetoplastida). Journal of Parasitology, v. 84, n. 6, p. 1267, 1998.

BORGES, A.R.; LEMOS, M.; MORAIS, D.H., SOUTO-PEDRÓN T. ; D'AGOSTO, A. In vitro culture and morphology of fish trypanosomes from South American wetlands. Journal of Microbiology and Infectious Diseases v. 4, n. 2, p. 1-5, 2018.

BUCKUP, P.A. Systematics and biogeography of stream fish. Oecologia brasiliensis, v. 6, n. 1, p 3, 1999.

BUSH A.; LAFFERTY, O.; LOTZ, J.M.; SHOSTAK, A.W. Parasitology Meets Ecology on Its Own Terms: Margolis et al. Revisited. Journal of Parasitology, v. 83, n.4, p. 575. 1997

CORRÊA, L.L.; OLIVEIRA, M.S.B.; TAVARES-DIAS, M.; CECCARELLI, P.S. Infections of Hypostomus spp. By Trypanosoma spp. and leeches: A study of hematology and record of these hirudineans as potential vectors of these hemoflagellates. Revista Brasileira de Parasitologia Veterinária, v. 25, n. 3, p. 299-305, 2016.

DE, CARLI G.A. 2001. Parasitologia Clínica: Seleção de Métodos e Técnicas de Laboratório para o Diagnóstico das Parasitoses Humanas. São Paulo: Editora Atheneu, 2001.

DE SOUZA, D.C.; CORRÊA, L.L. A comparative study of Trypanosoma sp. (Protozoa: Kinetoplastida) parasitizing four species of loricarides in the Brazilian Amazon. Biologia. v. 74, n. 9, p. 1163-1170, 2019.

DELARIVA, R.L.; AGOSTINHO, A.A. Relationship between morphology and diets of six neotropical loricariids. The Journal of Fish Biology, v. 58, n. 3, p. 832-847, 2001.

EIRAS, J.C.; REGO, A.A.; PAVANELLI, G.C. 1998. Trypanosoma nupelianus sp. $\mathrm{n}$ (Protozoa, Kinetoplastida) parasitando Rhinelepis aspera (Osteichthyes, Loricariidae) do rio Paraná, Brasil. Mem Inst Oswaldo Cruz, v. 85, n. 2, p. 183-184, 1998.

EIRAS, J.C.; TAKEMOTO, R.M. ; PAVANELLI, G.C. Diversidade dos parasitas de peixes de água doce do Brasil. Maringá: Clichetec, 2010.

EIRAS, J.C; TAKEMOTO, R.M.; PAVANELLI, G.C. LUQUE, J.L. Checklist of Protozoan parasites of fishes from Brazil. Zootaxa v. 25, n. 3221, p. 1-25, 2012.

FIGUEROA, F.; MAYER, W.E.; LOM, J.; DYKOVÁ, I.; WELLER, M.; PECKOVÁ, H.; KLEIN, J. Fish trypanosomes: Their position in kinetoplastid phylogeny and variability as determined from $12 \mathrm{~S}$ rRNA kinetoplast sequences. The Journal of Eukaryotic Microbiology, v. 46, n.5, p. 473-481, 1999. 
FONSECA, F.; VAZ, Z. Novos trypanosomas de peixes brasileiros. Anais da Faculdade de Medicina de São Paulo, v. 6, n. 1, p. 69-94, 1928.

FONSECA F.; VAZ Z. Novas espécies de trypanosomas de peixes brasileiros de água doce. Boletin de Biologia 13(1): 36-41, 1929.

FRÓES, O.M.; FORTES, E.; LIMA, D.F.; LEITE, V.R.V. Três espécies novas de tripanosomas de peixes de água doce do Brasil (Protozoa, Kinetoplastida). Revista Brasileira de Biologia, v. 38, n. 1, p. 461-468, 1978.

FRÓES, O.M.; FORTES, E.; LIMA, D.F.; LEITE, V.R.V. Tripanosomas (Protozoa, Kinetoplastida) de peixes de água doce do Brasil. II: novos tripanosomas de cascudos (Pisces, Loricariidae). Revista Brasileira de Biologia, v. 39, n. 1, p. 425-429, 1979.

FUJIMOTO, R.Y.; NEVES, M.S.; SANTOS, R.F.; SOUZA, N.C.; DO COUTO, M.V; LOPES, J.N; EIRAS, J.C. Morphological and hematological studies of Trypanosoma spp. infecting ornamental armored catfish from Guamá River-PA, Brazil. Anais de Academia. Brasileira de Ciência, v. 85, n. 3, p. 1149-1156, 2013.

GOMES, L.C.; CHIPPARI-GOMES, A.R.; LOPES, N.P.; ROUBACH, R.; ARAUJOLIMA, C.A. Efficacy of benzocaine as an anesthetic in juvenile tambaqui Colossoma macropomum. Journal of the World Aquaculture Society, v. 32, n. 4, p. 426-431, 2001.

GU, Z.; WANG, J.; LI, M.; ZHANG, J.; KE, X.; GONG, X. Morphological and genetic differences of Trypanosoma in some Chinese freshwater fishes: Difficulties of species identification. Journal Parasitology, v. 101, n. 3, p. 723-730, 2007.

GUPTA, N \& GUPTA, DK, G 2012. Erythropenia in piscine trypanosomiasis. Trends in Parasitology, v.1, n. 1, p. 1-6, 2012.

JONES, S.R.M ; WOO, P.T.K Development and infectivity of Trypanosoma phaleri in leech and fish hosts . Canadian journal of zoology, v. 69, n. 6, p. 1522-1529, 1991.

KARLSBAKK, E.; NYLUND, A. Trypanosomes infecting cod Gadus morhua L. in the North Atlantic: a resurrection of Trypanosoma pleuronectidium Robertson, 1906 and delimitation of T. murmanense Nikitin, 1927 (emend.), with a review of other trypanosomes from North Atlantic and Mediterranean teleosts. Systematic Parasitology, v. 65, n. 3, p. 175-203, 2006.

LEMOS, M.; FERMINO, B.R.; SIMAS-RODRIGUES, C.; HOFFMANN, L.; SILVA, R.; CAMARGO, E.P.; SOUTO- PADRÓN, T. Phylogenetic and morphological characterization of trypanosomes from Brazilian armoured catfishes and leeches reveal high species diversity, mixed infections and a new fish trypanosome species. Parasite Vectors, v. 8, n. 1, p. 1-17, 2015.

LETCH, C.A. The life-cycle of Trypanosoma cobitis Mitrophanow 1883. Parasitology, v. 80, n. 1, p. 163-169, 1980.

LOM, J. Experimental infections of freshwater fishes with blood flagellates. Journal Protozoology, v. 20, n. 1, p. 537, 1973.

LOPES, R.A.; LOPES, O.V.; SATAKE, T., GARAVELO, J. C. Trypanosomes of Brazilian fishes Ii T. vialeri sp.n. from Pterodoras granulosus Valenciennes, 1833 . 
Naturalia (Brazil), v. 16, n. 1, p. 19-29, 1991.

MAQBOOL, A.; AHMED, I. Haematological response of snow barbell, Schizothorax plagiostomus Heckel, naturally infected with a new Trypanosoma species. Journal Parasite Diases, v. 40, n. 3, p. 791-800, 2016.

MOLINA, J.P.; MADI, R.R.; SOLFERINI, V.N.; CECCARELLI, P.S.; PINHEIRO, H.P.; UETA, M.T. Trypanosomatids (Protozoa: Kinetoplastida) in three species of armored catfish from Mogi-Guaçu river, Pirassununga, São Paulo, Brazil. Revista Brasileira de Parasitologia Veterinária, v. 25, n. 2, p. 131-141, 2016.

NELSON, J.S. Fishes of the world. New York : John Wiley \& Sons, 1994.

NEVES, M.S.; COUTO, M.V.S.; SOUSA, N.C.; SANTOS, R.F.B.; DIAS, H.M.; ABE, H.A.; FUJIMOTO, R.Y. Resposta hematológica do cascudo ornamental amazônico Peckoltia oligospila ao estresse de transporte. Arquivo Brasileiro de Medicina Veterinária e Zootecnia, v.70, n. 1, p. 13-19, 2018.

NYLUND, A.; OTTEM, K.F.; WATANABE, K.; KARLSBAKK, E., KROSSOY, B. Francisella sp. (Family Francisellaceae) causing mortality in Norwegian cod (Gadus morhua) farming. Archives of Microbiology, v. 185, n. 5, p. 383-392, 2006.

REIS, R.E.; ALBERT, J.S.; DI DARIO, F.; MINCARONE, M.M.; PETRY, P.; ROCHA, L.A. Fish biodiversity and conservation in South America. Journal of Fish Biology, v. 89, n. 1, p. 12-47, 2016.

RIBEIRO, R.D.; LOPES, R.A.; SATAKE, T; SALA, M.A.; BRITSKI, H.Á. Trypanosomes of brazilian fishes. XIII. Trypanosoma birmani sp. n. from Hypostomus commersonii Valenciènnes 1840 (Pisces, Loricariidae), from Ribeira de Iguape river, SP. Brazil. Acta biologica leopoldensia, v. 13, n. 1; p. 75-84, 1991.

SANTOS, C.C.; SANT'ANNA, C.; TERRES, A.; CUNHA-E-SILVA, N.L.; SCHARFSTEIN, J.; LIMA, A.P.C.D.A. Chagasin, the endogenous cysteine-protease inhibitor of Trypanosoma cruzi, modulates parasite differentiation and invasion of mammalian cells. Journal of Cell Science, v. 118; n. 5, p. 901-915, 2005. 